\section{ZAVARITZKY'S PETROLOGICAL METHODS}

\section{BY S. I. TOMKEIEFF}

$\mathrm{M}$ ICROSCOPICAL petrology was first studied in Russia some eighty years ago and, reinforced by chemistry and physical-chemistry, made rapid progress, largely through the genius and the untiring efforts of such men as E. S. Fedorov (1853-1919) and F. Y. Levinson-Lessing (1861-1939). One of the most prominent Russian petrologists at the present time is Alexander Nikolaevich Zavaritzky, who was born in 1884 and for twenty years occupied the chair of petrology at the Mining Institute at Leningrad, one of the oldest establishments of its kind in the world.

It may be truly said that at the present time the development of science in the U.S.S.R. is characterized by a widespread interdigitation of the pure and the applied sciences. As a matter of fact this tendency was already manifest even before the Revolution of 1917, and in Zavaritzky we can see a typical representative of this tendency. In his first work on the platinum deposits of the Urals published in 1909, Zavaritzky successfully applied petrological methods to the elucidation of the difficult problem of the genesis of platinum, work which he continued later, and in 1928 he published a more extensive account. Following up the ideas expressed by some American petrologists and by A. P. Karpinsky, he rejected the previously held opinion that platinum was an early product of the crystallization of an ultrabasic magma, and definitely demonstrated that, together with chromite, platinum was formed by the late magmatic fluids. These fluids or mineralizers, as they are frequently called, formed part of the scientific credo of Zavaritzky, and in this he shared the opinion of many modern petrologists. This attitude towards the part played by the volatiles contained in the magma determined his subsequent work and made him revise previously held opinion on the genesis of the worldfamous magnetite ores of the Urals. In 1922 he published a most important work on the magnetite deposits of Mount Magnitnaya, which was afterwards amplified and revised ("Mount Magnitnaya" in the guide of the International Geological Congress, Moscow, 1937). He proved that the magnetite ore is not a product of magmatic segregation but is of a contact pyrometasomatic type replacing limestone of Carboniferous age adjoining intrusive granite. This new idea completely altered the character of the prospecting work in this area, and eventually led to a new and extensive mining of the ore which began in 1931, and to the construction of the greatest assemblage of blast furnaces in the U.S.S.R. and the building of the entirely new town of Magnitogorsk. The vastness of this enterprise is shown by the amount of extracted ore, which just before the War has risen to well over 5 million tons per annum, as compared with 20,000 tons per annum extracted before the Revolution.

Zavaritzky's work on the Uralian deposits of copper and iron pyrites is of no less importance. Since 1926 he has produced a series of papers on this subject in which he has gradually developed a new theory of the formation of these deposits. According to the previously held opinion, these ores were formed during the later phases of Uralian orogenesis and were deposited along tectonic crush zones. By discovering deposits of these ores among the less meta- morphosed rocks of the southern Urals, Zavaritzky has been able to prove that the metamorphism affected the ores only long after their formation and that the original ores were formed from magmatic fluids associated with the eruptive activity of the Devonian period. This theory not only opened up new avenues in the study of Uralian rocks, but also provided a useful guide for future prospecting; and many new localities of pyritic deposits have since been discovered among the less metamorphosed lavas and tuffs.

Zavaritzky's contributions to pure science are equally important. Unlike some petrologists, he is extremely averse from framing sensational hypotheses and indulging in nebulous speculation about the origin of rocks. All his work is characterized by a mastery of his data and a strict interpretation of facts in the light of physico-chemical laws and mathematical reasoning. This mastery of facts and attention to detail is clearly seen in his excellent description of the peridotite massif of Rai-Iz in the polar Urals, published in 1932, and in the description of other peridotites from the same region, published in 1937. In this work, using his field and laboratory data as a starting point, he went deeply into a discussion of the processes of metasomatism, hybridization and contamination and all their bearings on petrogenesis.

Besides the Urals, Zavaritzky has made himself at home in another part of the U.S.S.R.- the fardistant peninsula of Kamchatka-a magnificent volcanic region containing nearly a hundred and thirty active and extinct volcanoes. In 1931 he began exploring the volcanoes of Kamchatka, on which subject he published several papers, and at the present time he is director of the Volcanological Station on Kamchatka. $\mathrm{He}_{e}$ is also responsible for many works dealing with Uralian volcanicity and tectonics, with various igneous, metamorphic and sedimentary rocks and on the classification of ore deposits.

Probably the most characteristic feature of Zavaritzky's work is his insistence on precise observation and on a strictly logical method of deduction. This explains the meticulous presentation of field and laboratory data and the interest he attaches to the optical study of rock-forming minerals. As his successor in the Mining Institute, he improved Fedorov's method of the universal stage, especially as applied to the determination of feldspars under the microscope; and he also worked out various refined methods for the determination of birefringence, refractive index, optical sign and other optical constants of the minerals.

At the same time Zavaritsky is probably the greatest authority in the U.S.S.R. on petrogenesis and on the application of physico-chemical principles to petrology. In his book "Physico-Chemical Principles of the Petrography of Igneous Rocks", published in 1926, he gave an excellent summary of the application of the phase rule and equilibrium diagrams to the study of artificial melts and magmas, combined with a critical discussion of the methods used and results achieved. In this book he also introduced a new method of graphic representation of rock analyses, a method which he later developed and which he has now used as the foundation of a most elaborate treatise on the chemical composition of igneous rocks, recently published under the title "Introduction to the Petrochemistry of Igneous Rocks" (Pub. Acad. Sci. USSR; 1944). This book of 321 pages will be of great value to petrologists of other countries provided they can read Russian, for it 
contains an elaborate discussion of the petrochemistry of various well-known petrographical provinces as well as very valuable chapters on geochemistry and crystal chemistry in relation to the composition and mode of formation of igneous rocks and an interesting discussion on the problem of rock classification and differentiation of magma. It would be rather difficult to explain here in detail his graphical method of representation of rock analyses which, in its essence, is a complete geometrization of chemistry. This method, in brief, consists in the recalculation of the chemical analysis as a number of coefficients expressing the relative amounts of chemical elements, and then the ten coefficients thus obtained are plotted on an opened-up rectangular tetrahedron. Each analysis is represented by two vectors the position, length and inclination of which characterize the composition of the rock in question. By means of these diagrams he is able to survey large assemblages of rocks and also to compare various assemblages and discuss the problems of petrogenesis. Whether this method is really more efficient for coping with these problems than the previously devised schemes of Osann, Niggli, Wolff and others, can only be tested by an actual trial.

In his latest paper (Bull. Acad. Sci. URSS, Ser. Geol., No. 5, 12; 1944) Zavaritzky returns to the discussion of the equilibrium diagrams as applied to systems composed of a silicate melt and a volatile constituent. Although only an ideal case is discussed, his elaborate analysis of the processes which are liable to occur in this system through changes in concentration, temperature or pressure has an important bearing on the genesis of pegmatites and hydrothermal veins.

In conclusion, one can truly say that Zavaritzky has really made very important contributions to the progress of petrology and especially to the problems of petrogenesis and ore genesis, and it is only because the Russian language is not better known among soientific workers of other countries that his work has not been fully appreciated. It is true that many of his works have been abstracted in the Mineralogical Abstracts published by the Mineralogical Society, but no abstract, however full, can adequately represent the original. Adherence to facts and methods of exact observation are the main characteristics of Zavaritzky's work, and in his own words : "I consider that the fundamental object of science is the acquisition of the knowledge of new facts about real things and a precise statement of such facts and not agreement with such or such hypothesis, postulate, opinion or idea".

\section{GLACIAL GEOLOGY IN HOLLAND DURING THE WAR}

\section{BY D. DE WAARD}

Mineralogical Geological Institute, University of Utrecht

$\mathrm{D}$ URING the War, Dutch geological students were unable to undertake much of the field-work usually done in foreign countries. Most of them carried out research on the carboniferous and cretaceous beds in the south of the Netherlands, or the tertiary and younger formations in the rest of the Netherlands. The following is a brief summary of progress made in geological research on the glacial Pleistocene in the Netherlands during the War.
For some decades, it was a well-known fact that, though all research pointed to only one glaciation having covered a part of the Netherlands especially during the Riss glaciation, yet remarkable differences are found in the kinds of sedimentary erratics in the boulder clay from different localities. These differences have been ascribed to variations in the direction of the glacial stream within the Baltic Sea area, whereby East and West Baltic erratic associations appear near each other in the boulder clay.

Besides these, great differences have recently been found in the proportions of recognizable crystalline erratic rocks in the north-east Netherlands. Usually the associations of the recognizable crystalline erratics contain only about 20 per cent East Baltic stones, consisting of Rapakivi granites from the Alands Isles and southern Finland, and other kinds of stones from this area. This percentage proved to be typical of the deposits of the Riss glaciation. So it was very interesting to find in the north-east Netherlands an association with a much higher percentage of East Baltic rocks agreeing with the glacial deposits of the older Mindel glaciation in northern Germany. Some Dutch geologists have suggested as an explanation of these phenomena the existence of an older glaciation in this part of the Netherlands, though no other indications of a second glaciation have been found.

Further, some forty years ago, a theory of more than one ice-cover of a part of the Netherlands was based on the presence of different coloured boulder clays. This theory was rejected long ago, for the colour differences proved to be caused by normal weathering of the boulder clay. As, however, these arguments may be partly true, this theory should have further consideration.

To summarize, though only one glaciation has covered a part of the Netherlands, there are remarkable qualitative differences in the sedimentary erratics, quantitative differences in the recognizable crystalline erratics and-in addition to those caused by weathering-differences in the colour of the boulder clay, mainly found in the northern and north. eastern parts of the Netherlands.

More or less by accident, I found an explanation of these phenomena in the sea bottom of the former Zuyder Zee. Surveying the glacial deposits in the part of the Zuyder Zee reclaimed since 1940-the so-called north-eastern polder-between the former Isle of Urk and the old west coast near Vollenhove, I discovered several well-separated blocks of a typical boulder clay in the normal boulder clay. These blocks may be small or large, usually some 10-20 yards in diameter, mostly with an irregular outline and some. times twenty within a square mile. They lie in the surrounding boulder clay, partly or wholly covered by it.

In contrast to the normal surrounding boulder clay, which in the unweathered condition is dark grey or nearly black and may be weathered to a rusty brown or even bluish-grey, the boulder clay of these separated blocks has a carmine or hæmetitic colour. None of the colours of the normal boulder clay in the weathering series approaches this carmine reddish colour.

Besides the colour differences, the boulder clay of the separated blocks differs from the surrounding boulder clay in a great many ways. For example, it contains mostly sedimentary erratics from the East Baltic area, not found in normal boulder clay; it has a high percentage of Rapakivi granites and other recognizable East Baltic crystalline erratics, while 